\title{
The systems and signs of political militants in/of Brazilian nursing
}

\author{
Os sistemas e signos de militantes políticos na/da enfermagem brasileira \\ Los sistemas y signos de militantes políticos en/de la enfermería brasileña
}

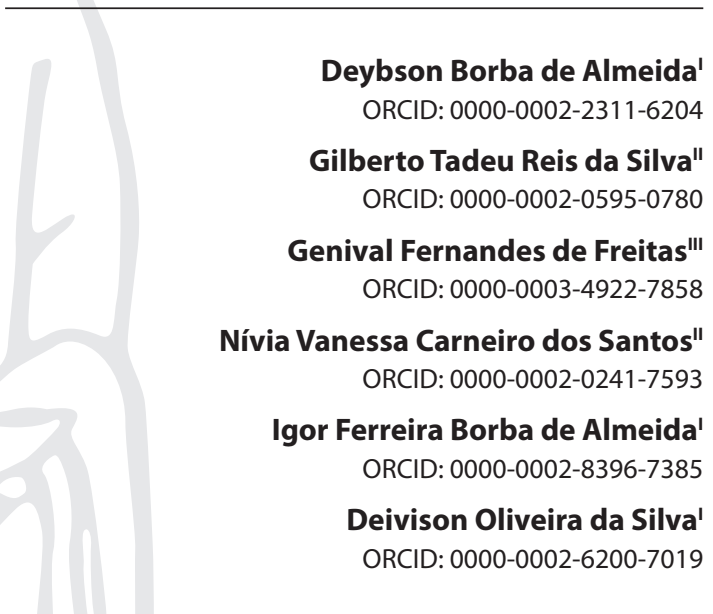

'Universidade Estadual de Feira de Santana. Feira de Santana, Bahia, Brazil. "Universidade Federal da Bahia. Salvador, Bahia, Brazil. "'Universidade de São Paulo. São Paulo, São Paulo, Brazil.

How to cite this article: Almeida DB, Silva GTR, Freitas GF, Santos NVC, Almeida IFB, Silva DO. The systems and signs of political militants in/of Brazilian nursing. Rev Bras Enferm. 2020;73(5):e20180971. doi: http://dx.doi.org/10.1590/0034-7167-2018-0971

\section{Corresponding author:} Deybson Borba de Almeida E-mail: dbalmeida@uefs.br

EDITOR IN CHIEF: Dulce Aparecida Barbosa ASSOCIATE EDITOR: Antonio José de Almeida Filho

Submission: 02-11-2019

Approval: 09-14-2019

\begin{abstract}
Objectives: to analyze the systems and signs in the constitution of militant nurses. Methods: a historical and qualitative research based on oral history carried out with 11 nurses who had been working in the professional field since 1980. Data collected from semi-structured interviews were organized into NVivo software 10, being analyzed through dialectical hermeneutics. Results: systems and signs are systems that allow us to use senses, symbols or meaning to objectify and subjectivate the subject. The revealed senses were categorized and divided into improper, religious, heroic, communist, and socially involved. Conclusions: militancy signs are convergent with what is put in national and international literature. The difference found was in the heroic sense and implicated with the social. Militant is almost never associated with positive aspects. An individual who builds himself as a political being empowers himself as a social being, making knowledge of power, generating a break in traditional models.

Descriptors: Nursing; Politics; Leadership; History of Nursing; Systems.
\end{abstract}

\section{RESUMO}

Objetivos: analisar os sistemas e signos na constituição de enfermeiras militantes. Métodos: pesquisa histórica baseada no método de história oral, com abordagem qualitativa, realizada com 11 enfermeiras que militaram/militam por questões profissionais desde 1980. Os dados coletados das entrevistas semiestruturadas foram organizados no software NVivo 10 e analisados através da hermenêutica dialética. Resultados: sistemas e signos são sistemas que permitem utilizar sentidos, símbolos ou significação para objetivar e subjetivar o sujeito. Os sentidos revelados foram categorizados e se dividiram entre: impróprio, religioso, heroico, comunista e implicados com o social. Conclusões: os signos da militância são convergentes com o que está posto na literatura nacional e internacional. A diferença encontrada foi no sentido heroico e implicado com o social, o militante quase nunca é associado a aspectos positivos, pois um indivíduo que se constrói ser político se empodera enquanto ser social tornando conhecimento poder, gerando uma quebra nos modelos tradicionais.

Descritores: Enfermagem; Política; Liderança; História da Enfermagem; Sistemas.

\section{RESUMEN}

Objetivos: analizar los sistemas y signos en la constitución de enfermeras militantes. Métodos: investigación histórica, basada en el método de historia oral con abordaje cualitativo, realizada con 11 enfermeras que militarizaron/militan por cuestiones profesionales desde 1980. Los datos recolectados de las entrevistas semiestructuradas fueron organizados en el software NVivo 10 y analizados a través de la hermenéutica dialéctica. Resultados: los sistemas y signos son sistemas que permiten utilizar sentidos, símbolos o significación para objetivar y subjetivar al sujeto los sentidos revelados fueron categorizados y se dividieron entre: inapropiado, religioso, heroico, comunista e implicados con lo social. Conclusiones: los signos de la militancia son convergentes con lo que está puesto en la literatura nacional e internacional, la diferencia encontrada fue en el sentido heroico e implicado con lo social, el militante casi nunca se asocia a aspectos positivos, pues un individuo que se construye ser político se empodera mientras sea social haciendo conocimiento de poder, generando una ruptura en los modelos tradicionales.

Descriptores: Enfermería; Política; Liderazgo; Historia de la Enfermería; Sistemas. 


\section{INTRODUCTION}

Militancy is a form of critical and articulated political participation, which develops actions aimed at bringing political awareness to the population, seeking out new values that allow people to organize themselves and fight for the development of a fair and dignified society ${ }^{(1)}$.

In the health field, militancy can be expressed in the stakes held at the meeting of workers, managers and users as a space to produce life, self-invention and the world. Therefore, at the moment those actors create relations among each other, multiple agencies arise and may point towards the production of something that goes beyond what is called health production ${ }^{(2)}$.

In nursing, political militancy is deemed essential to pave the path to change, with an integral view that is ethically, politically and socially committed to human beings and to Brazilian society, thus excessive settling down and unquestioned acceptance must be avoided, what turns the profession, oftentimes, into a repetitive and uncreative practice ${ }^{(3)}$.

However, it was identified that Nursing training remains predominantly supported in the clinic model, which is guided by a medic-centric conception of health/sickness that is cure focused, biologicist, highly specialized, fragmentary, thus resonating the weaknesses of political dimension in nursing training ${ }^{(4)}$.

Nursing is a knowledge area that presents several historical and social determinant factors that place it in a trencher of social exclusion, subjugation, invisibility, lack of identity among its professionals, which goes through technicist training of proletarian basis, where the great determining axis is sex, thus touching women's social construction.

In this context, this study seeks to use signs, meanings and symbols or significations to objectify and subjectify the subjects, according to a Foucaultian conception, so these aspects can assist to the understanding of the researched phenomenon, thus arises the question: how do systems and signs allow the unveiling of militant beings/knowledge in nursing?

In other words, this article seeks to understand how nurses trained under predominantly hegemonic models break away from domination and how symbols and signs can assist the understanding of that process, guided by a Foucaultian conception and by dialectic hermeneutics.

The sign can be understood as what is presented to the senses or to the intellect, it designates something to the intellect and it depends on a complexity of the latter's factors so it can be truly deciphered, especially the passions, the dispositions and assumed forms of things in the intellect ${ }^{(5)}$.

For example, Foucault does not treat discourse as a document, but as a sign for something, as an element that should be transparent but whose inopportune opacity must frequently be pierced to find once more, where it is kept away, the depth of essence ${ }^{(6)}$.

To some extent, every sign has its codification marked by two aspects: the first one aims at appeasing consciences, usually when the symbol is directed towards what is already known; the second one directs human behaviors related to the sign, causing the rupture or maintenance of power relations.

Discourse is made of signs, but what it does goes beyond using those signs to designate things. This "beyond" is irreducible to language and speech. It is that "beyond" that must be brought to light and described, because that "beyond" will certainly be run through with truth and power games ${ }^{(7)}$.

It is also necessary to distinguish power relations to communication relations, which send an information through a language, a system of signs or any other symbolic means. Doubtlessly, communicating is always, in some way, to act upon others or in others. However, production and circulation of significant elements may perfectly hold in its objectives, on in its consequences, power effects ${ }^{(8)}$.

Finally, it must be mentioned that the present study is a product of a doctor's degree thesis that was based on the theoretical referential of Michel Foucault, a philosopher who sought to understand the subject in all of its dimensions.

\section{OBJECTIVES}

To analyze systems and signs in/of political militancy in/of nursing.

\section{METHODS}

\section{Ethical aspects}

This study was approved by the Research Ethics Committee of Universidade Federal da Bahia/Nursing School under protocol CAEE n. 28775614.2.0000.5531, dated May 27, 2014. The research process obeyed all recommended ethical standards for research.

\section{Type of study}

This is a study of qualitative character, based on the Oral History method, which presents itself as a systematic approach through collection, organization and critical assessment of data that is related to past occurrences. Some steps are deemed essential to the production of a historical work: 1 ) definition, justification and delimitation of the theme; 2 ) research goals; 3 ) theoretical chart and hypothesis; 4) collection of source data; 5) data criticism and validation; and 6) data analysis and interpretation ${ }^{(9)}$. Further regarding the choice of methodology in this study, Oral History method is a way to establish relations of greater quality and depth between researcher and study participants, considering that, in this research, it was intended to reveal narratives as tools to see them through themselves, which are in the biographic type ${ }^{(10)}$.

\section{Methodologic procedures}

This study used the semi-structured interview technique and the snowball technique, through which it was possible to identify and have as study participant nurses who were presidents of the Brazilian Nursing Association (ABEn - Associação Brasileira de Enfermagem) and of the Nurses' Union of the State of Bahia (SEEB - Sindicato dos Enfermeiros do Estado da Bahia) as well as those who did not preside ABEn or SEEB but who had or have a socially acknowledged militancy.

From an operational point of view, data collection followed two moments:

- Firstly, for selection of "seeds", based on a single inclusion criterion: having a presidential mandate in ABEn - Bahia Chapter and/or in SEEB, starting from the 1980's; 
- Secondly, to identify the daughters/sons of the "seeds", through some preestablished criteria: being a nurse; militating about profession-specific political matters, as well as for professional valuing, visibility, respect and acknowledgement, for a time lapse of at least a year, in a systematic, regular and sociallyacknowledged way, counting the timeframe from the 1980's onwards; organizing and participating in public movements and social mobilizations about nursing.

As an exclusion criterion, a limit of five contact attempts to schedule an interview was established; after that, the militant was excluded from the sample, what happened to two individuals. For all others, data collection was suspended at the moment answer saturation was reached.

The chosen timeframe was selected due to the effervescence of social movements in the 1980's, which created more freedom of speech and, therefore, collaborated to the expression of political militancy. The chosen spatial coverage of this study is due to the records of the political movement of nurses from Bahia in the national and international scene.

\section{Study setting}

The state of Bahia, located in the Northeast Region of Brazil, has an area of $564.733,081 \mathrm{~km}^{2}$ and it is the fifth largest one in the country. Its population was estimated in 2015 to be 15.203 .934 people ${ }^{(11)}$.

Upon consultation to the Regional Nursing Council (Conselho Regional de Enfermagem) - Bahia Chapter, it was found that there are 17 thousand nursing assistants, about 60 thousand $(60,220)$ nursing technicians and approximately 27 thousand $(27,447)$ nurses, adding up to over 104 thousand $(104,667)$ professionals in the area ${ }^{(11)}$.

\section{Data collection and organization}

After telephone contact and previous scheduling, interviews were carried out individually in a private space, conducted by a trained professional, and lasting for approximately 2 hours and 55 minutes. Data were collected from July to December 2015.

An interview script divided into four blocks was used: political militancy in nursing, correlating it to social movements of the researched timeframe; election process of formal representatives of nurses; and life trajectory of the militant subject. Interviews were recorded and later transcribed fully.

Ten female nurses and one male nurse collaborated to this study. However, due to sex issues, the female reference is adopted whenever necessary. To identify the speakers, the name Rosa dos Ventos (Compass Rose) was adopted, with poetic license to the song by Chico Buarque de Holanda (Chico Buarque de Holanda (1944) is a
Brazilian musician, playwright and writer), followed by the respective number to the sequence the interviews were made in.

\section{Data analysis}

In order to analyze the data, the method of Dialectic Hermeneutics based on Comprehensive Sociology was used, which contains two core aspects: the theory of experience and the theory of reconstruction. It was sought, based on the lived experiences of the nursing political militants in the construction of the phenomenon, to find their liberty practices directed to other modalities of objectification, which counterpointed the logics of subjectification and subalternity existing in the profession ${ }^{(12)}$.

Operationally, upon analysis of data and interviews, attention was paid to the following steps: Level of fundamental determinations: which corresponds to the exploratory phase of investigation; Data organization: which comprises the systematization of all collected data; Data sorting: where it is necessary to understand data don't exist by themselves, but are built by the exercise of questioning them, based on theoretical fundamentals; Final analysis: moment when the articulation between collected data and theoretical-philosophical references of the research is established ${ }^{(13)}$.

During data organizing, the software NVivo 10 for Windows was used in order to sort speech extracts by meaning cores. This software is largely used in health research of qualitative approach, including other areas, such as Anthropology, and in many countries, such as Australia and the United Kingdom.

After that step, confronting the theoretical-philosophical reference of the thesis with the possibilities presented by NVivo, the following analysis chart was developed and the category and its respective subcategories for analysis were built: Improper meaning, religious meaning, heroic meaning, communist meaning, and meaning implied with social matters.

In this study, through data pre-analysis, one of the subject comprehension techniques herein employed is the sign systems technique, which allows the use of signs, meaning, symbols or signification. It is represented in the study through the category: constitutive aspects of militants in nursing: systems and signs.

\section{RESULTS}

Systems and signs in the build-up of militant subjects make it possible to use signs, meanings, symbols or signification to objectify and subjectify the subject, and such aspects may assist the understanding of the researched phenomenon.

Meanings and signs are correlated to the political militant, with highlight to: improper, religious, heroic, communist, and implied with social matters, as shown in the Charts 1, 2, 3, 4 and 5 .

Chart 1 - Constitutive aspects of militants in nursing: systems and signs

\begin{tabular}{|l|c|}
\hline \multicolumn{1}{|c|}{ Corpus } & $\begin{array}{c}\text { Hermeneutic- } \\
\text { dialectic } \\
\text { synthesis }\end{array}$ \\
\hline $\begin{array}{l}\text { [...] a lady of good status going to, how do you say it, to demonstrations, only if it were a very different thing. [...] now you have a husband } \\
\text { who, at the time he's at home, he won't want a wife who's going to and fro making politics, you see? [...] (Rosa dos Ventos 1) }\end{array}$ & Improper \\
\hline $\begin{array}{l}\text { [...] that the women who belonged to the militancy either were lesbians, because to be able to go there you had to be a lesbian, or if they } \\
\text { had husbands they were cheating on their husbands, then he would tell me: "What do you think it is?" [...] (Rosa dos Ventos 2) }\end{array}$ & Meaning \\
\hline
\end{tabular}




\begin{tabular}{|c|c|}
\hline Corpus & $\begin{array}{l}\text { Hermeneutic- } \\
\text { dialectic } \\
\text { synthesis }\end{array}$ \\
\hline $\begin{array}{l}\text { [...] because if you take the communications of nursing professionals themselves, even in REBEn, you will see that there are many } \\
\text { works, [...] also nurses, they couldn't be, they had to be that sort of tranquil lady, obedient, who couldn't... how do you say, be involved } \\
\text { in politics, naturally, politics was men's business and not women's, and Nursing also has this thing that it is [...] Christian spirit and } \\
\text { obedience and there is this group that already rebelled against that, isn't it?! [...] (Rosa dos Ventos 4) }\end{array}$ & \multirow{4}{*}{$\begin{array}{l}\text { Improper } \\
\text { Meaning }\end{array}$} \\
\hline $\begin{array}{l}\text { [...] men are not afraid of power, women are not raised to have it, I think that, as I told you, nobody raises anybody for militancy (...) in } \\
\text { school I was never one to disrespect, I was respectful, always listened to authority as authority, but I raised arguing points so I was the } \\
\text { hippie, more than the communist, the communist was (another student) [...] I never was a political militant, they say political militants } \\
\text { are the worst students, but I never had a low grade [...] (Rosa dos Ventos 6) }\end{array}$ & \\
\hline $\begin{array}{l}\text { [...] well, if power is tied to the male question, it's obvious that people from National Association of Nursing Assistants and Technicians } \\
\text { had more strength than those from ABEn, because they have way more men, I don't want to say with this that there aren't women with } \\
\text { the ability to discuss politics and everything. [...] sex issues are a strong element to the analysis of any theme that involves nursing, } \\
\text { especially when it comes to drawing a parallel to political militancy, which is historically a space of male power. [...] (Rosa dos Ventos 10) }\end{array}$ & \\
\hline $\begin{array}{l}\text { [...] sex issues certainly interfere with political militancy. I think that is something that weights in a lot, militancy, it ends up being seen way more as } \\
\text { a male space. Women, because they have their second and third shifts, they also face a lot of difficulty to be in militancy, from a point of view od } \\
\text { management, of positions, of union positions, or in associations, they are seen so much as male spaces [...]. To the point that sex issues will crossover } \\
\text { there, mainly, due to a stereotype that that is a male space and who goes there will become masculine, will be fighting, "Ah, this one won't be able to } \\
\text { take care of the house, of a husband, of children", because the most expected role for women is to get married, take care of the house and of children. } \\
\text { Being in militancy is to be in the world of the streets, which is not the private world that society expects for women. [...] (Rosa dos Ventos 11) }\end{array}$ & \\
\hline
\end{tabular}

Note: ANATEN - ; ABEn - Associação Brasileira de Enfermagem (Brazilian Nursing Association).

Chart 2 - Constitutive aspects of militants in nursing: systems and signs

\begin{tabular}{|l|l|}
\hline \multicolumn{1}{|c|}{ Corpus } & $\begin{array}{c}\text { Hermeneutic- } \\
\text { dialectic } \\
\text { synthesis }\end{array}$ \\
\hline $\begin{array}{l}\text { [...] so at the time and in so many things there's the matter of you having to dress like a nun, that you... Is there anything worse than } \\
\text { saying the patient is sexless? By the heavens, seriously, and that we had no sex? That we couldn't cry, that we couldn't get emotional. It } \\
\text { was how we were raised, but how will I take care of someone who's there, which I think is the most delicate thing in the life of a human } \\
\text { being, it is you, beautiful, professional, hard-working, it is, with all the possibilities to see yourself in a bed, depending on someone, and } \\
\text { this person says you're not a man, for God's sake, that is horrible [...] (Rosa dos Ventos 2) }\end{array}$ & Religious \\
\hline $\begin{array}{l}\text { [...] that experience made me realize the strong influence of our origins related to religion and to sex, because the "money" issue is very } \\
\text { hard. We don't know how to work the financial issues, we deny its necessity, that is to say, the importance of economic valuing of work, } \\
\text { but we actively participate in the healthcare market [...] it is not discussed to bring forth [...] [the topic] of money, it's like sin, like you're a } \\
\text { capitalist. [...] I remember when I went to the ABEn congress, there were a lot of nuns that, for us to see the lecturer, we had to turn to look } \\
\text { past the hats and veils, besides, I remember that a deputies' assembly was suspended so everyone could attend mass. [...] men, since they } \\
\text { are little, are used not to cry, are used to have power, while women are forced to be submissive [...] mass was prayed here at the School as } \\
\text { well as in ABEn in the beginning of assemblies, so this thing is very strong. [...] (Rosa dos Ventos 10) }\end{array}$ \\
\hline
\end{tabular}

Note: ABEn - Associação Brasileira de Enfermagem (Brazilian Nursing Association).

Chart 3 - Constitutive aspects of militants in nursing: systems and signs

\begin{tabular}{|c|c|}
\hline Corpus & $\begin{array}{l}\text { Hermeneutic- } \\
\text { dialectic } \\
\text { synthesis }\end{array}$ \\
\hline $\begin{array}{l}\text { [...] the suffering of the current president must be horrible, because the president was the vice-president for another one, later she took over } \\
\text { and we don't know what will become of ABEn... Get it? [...] she does it, if she is president, she gets things done, she does it daily, she wants to } \\
\text { do more than routine, if she has availability and time. [...] (Rosa dos Ventos 1) }\end{array}$ & \multirow{3}{*}{$\begin{array}{l}\text { Heroic } \\
\text { Meaning }\end{array}$} \\
\hline $\begin{array}{l}\text { [...] a militant has to be a person who is able to, even with all the workload, with matters like children, husband, problems, but she is always willing to } \\
\text { discuss, to forward projects, she doesn't only do that you know, it's not just that routine thing, she tries to innovate, she is always updated as well as } \\
\text { the others, the old ones also got update, but the militant too [...] I remember as president of ABEn, oh my God what an annoying thing, it is very bad, } \\
\text { because you have to be there in the militancy defending even, for example, the career and salary plans of institutions [...] (Rosa dos Ventos 4) }\end{array}$ & \\
\hline $\begin{array}{l}\text { [...] but obviously women who have a political involvement, who have a different gaze for those matters, they overcome all those matters, they'll } \\
\text { be there with her child on her lap, breastfeeding her child or with the child in the crib. Countless times in Brazilian nursing congresses we see } \\
\text { nursing directors asking us to provide cribs and whatnot, because they're taking a small child, bringing a babysitter, or resorting to taking their } \\
\text { mothers along [...] (Rosa dos Ventos 11) }\end{array}$ & \\
\hline
\end{tabular}

Note: ABEn - Associação Brasileira de Enfermagem (Brazilian Nursing Association).

Chart 4 - Constitutive aspects of militants in nursing: systems and signs

\begin{tabular}{|l|c|}
\hline \multicolumn{1}{|c|}{ Corpus } & $\begin{array}{c}\text { Hermeneutic- } \\
\text { dialectic } \\
\text { synthesis }\end{array}$ \\
\hline $\begin{array}{l}\text { [...] the group that had this more critical view and that articulated with the more general social movement, it was understood like this, it } \\
\text { was the communists, however, none of us had any filiation. [...] I think it was seen so by the school professors, the more traditional ones, } \\
\text { they thought that the posture of the students' movement was one of rebellion [...] (Rosa dos Ventos 5) }\end{array}$ & $\begin{array}{c}\text { Communist } \\
\text { Meaning }\end{array}$ \\
\hline
\end{tabular}




\begin{tabular}{|l|l|}
\hline & $\begin{array}{c}\text { Hermeneutic- } \\
\text { dialectic } \\
\text { synthesis }\end{array}$ \\
\hline $\begin{array}{l}\text { [...] speaking about the collective view at the time (a nurse) was a good one to be the first president of the Union, because (she) always } \\
\text { was, she like this communism thing. I was a face to be in the Union, because I was communist, so, but I will tell you that (someone who } \\
\text { was a director of ABEn) was not a face for the Union. (someone who was a President of ABEn) never was a face for the Union, she was } \\
\text { for other political struggles [...] (Rosa dos Ventos 6) }\end{array}$ \\
\hline $\begin{array}{l}\text { [...] a classmate who took part in the academic directory was called subversive, he was shunned by some peers and harassed by some } \\
\text { professors, [...] the professors were implanted to be there, looking, seeking students who participated in the movement and who were } \\
\text { identified as subversive by those professors, and many students were arrested [...] (Rosa dos Ventos } 8 \text { ) }\end{array}$ \\
\hline
\end{tabular}

Note: ABEn - Associação Brasileira de Enfermagem (Brazilian Nursing Association)

Chart 5 - Constitutive aspects of militants in nursing: systems and signs

\begin{tabular}{|c|c|}
\hline Corpus & $\begin{array}{l}\text { Hermeneutic- } \\
\text { dialectic } \\
\text { synthesis }\end{array}$ \\
\hline $\begin{array}{l}\text { [...] a political militant nurse, I'll make an effort. I think this person, she articulates her praxis with a more general context, either in the } \\
\text { institution or in society as a whole [...] I think this person, that's why I said she articulates herself, she would tend to have a less rigid } \\
\text { stance in relation to what is established. Norm by the norm, hierarchy. She would tend to be more, to have a more collective work, more } \\
\text { participative, but I can't see this profile as clearly as you put it [...] (Rosa dos Ventos 5) }\end{array}$ & \multirow{3}{*}{$\begin{array}{l}\text { Meaning } \\
\text { implied with } \\
\text { social matters }\end{array}$} \\
\hline $\begin{array}{l}\text { [...] we were always taught to have solidarity with, with the poor, there was this thing that, respectable to see, to help, to take things, to visit [...] } \\
\text { when I came to live here, when I got to know the city of Salvador, it shocked me a lot here, because all, all poverty that I saw in my childhood, } \\
\text { it had a layer of dignity. [...] so, it was like that, I said, people, they were poor but they worried about the beauty of the place, so on, when I } \\
\text { knew the misery in the outskirts of Salvador I was very shocked, because it was completely different from poverty in my town, my town had a } \\
\text { particularity that I think that marked my social identity, it was, the lunatics in my town, all of them were sustained by the community. [...] so the } \\
\text { city somehow taught me that those people were just different, but they weren't excluded, right? [...] (Rosa dos Ventos 6) }\end{array}$ & \\
\hline $\begin{array}{l}\text { [...] because it's that way as soon as you incorporate those perspectives in your life. Race, sex, you cannot look at race, sex without looking } \\
\text { at social class matters too, so you look at content not only through the technical perspective, but also through the political one, of how } \\
\text { it develops within the processes of health policies. And then there is the participation in conferences, in spaces where we can make it so } \\
\text { politics get a little closer to that which you believe is the best for the population and that you can contribute with [...] (Rosa dos Ventos 11) }\end{array}$ & \\
\hline
\end{tabular}

\section{DISCUSSION}

Initially, Michel Foucault states the means of subjectivation of the meanings sustain the objectification of things, and in this set of results we highlighted such processes. By understanding the history of nursing, its professionalization and finally the political, economic and social aspects that form the context of such a phenomenon, tied to the findings of signs of militants in the profession as improper, communist and/or with a religious sense, an explanation matrix is found for the fragility of nursing militancy in the international and national reach.

From a concept perspective, the sign is the one that presents itself to the senses or to the intellect, designates something to that intellect and depends on a complexity of the latter's factors so it is truly deciphered, specially the passions, dispositions and assumed forms of things in the intellect ${ }^{(14)}$.

Therefore, we shall discuss the improper and communist sign/ meaning, due to understanding these symbolic representations is articulated to the disciplining system of bodies and of the profession.

In general, the stereotype of a militant is heavily influenced as a male, improper, rebellious and disturbing place. Therefore, through those political fetishes, political alienation and political delegation are achieved, thus a fictitious person comes to existence, an incarnated mystical body named mandatary ${ }^{(15)}$.

Fetishism is not by priority a conscience phenomenon, but rather a set of social objectivity manifestations, or, more accurately, manifestations of objectifying the crystallization of certain social practices, social objects, so that codifying activity ensures the learning and acquisition of crystallized skills or behavior patterns which serve them as material support, i.e., social relations, overhead from individuals, which produce and reproduce consistent social objects ${ }^{(16)}$.

The meanings discovered about the political militant result in the fragility of militancy in nursing. Most nurses seek out social acknowledgement that is not bound to the image of rebelliousness and of an improper professional category.

Attributes and adjectives present in the speeches of the improper meaning subcategory correlate the militant role to a rupture to the social role of women, as it is connected to masculinity, destined to women of homosexual orientation or of adulterous nature. They are figures who are outside the normalizing sanction of western society that works as a punitive mechanism and has its own laws. They are used as punishment, turning the most tenuous conduct situations reprehensible and granting punitive function to the apparently indifferent elements of disciplinary apparatus: taken to the extreme, it is so that everything may be used to punish the slightest thing; that each individual be stuck in a punishable-punishing universality ${ }^{(17)}$.

Regarding data, the speeches are highly convergent in this subcategory, when they express sex matters as a preponderant factor to the fragility of political militancy in nursing. However, interviewee Rosa dos Ventos 6 reinforces that nobody teaches anybody to be a militant, as well as the fear she felt of being punished for being who she was, as she was tied to the stereotype of the hippie movement.

Another meaning that was correlated to the figure of the militant was that of the communist, linked to the system of body disciplining, and which is expressed in the speech of Rosa dos Ventos 5, 6 and 8. As such, initially, nurses of a "communist" 
stereotype were improper to work in the Association and were pointed towards work at the Union.

In order to understand that perception, it is highlighted that in Brazil, especially in the 1930's, 1960's and 1970's, communists were seen as criminals, identified by their political and ideological action, who became preferential targets of repression, thus making the number of arrests to increase substantially. This "mass incarceration" created, thus, new stereotypes of transgressions to the law, in alliance with the strategy of isolating political prisoners ${ }^{(18)}$.

Power relations themselves are carried out by an extremely important aspect, through the production and exchange of signs, and they also are not dissociable of finished activities, whether it is those which allow one to exert that power (such as training techniques, domination procedures, ways to obtain obedience), or whether it is those that unfold to self-sustain (such as in labor division and in task hierarchy) ${ }^{(19)}$.

Such codifying activity ensures the learning and skill/behavior acquisition, followed by the development of a set of regulated communications (lessons, questions and answers, orders, exhortations, codified signs of obedience, differential marks of "value" and of knowledge levels) and through a whole series of power procedures (incarceration, vigilance, reward and punishment, pyramidal hierarchy) ${ }^{(20)}$.

Another subcategory that came into evidence was that of religious meaning, bound to the limitation of political militancy, and also related, in Foucaultian analysis, to subject disciplining practices. Especially the speech of Rosa dos Ventos 10 shows the difficulty to deal with the economic value of nurses' work, and the religious influences to the militancy and training of nurses.

Despite the fact one of the manifestations of modern militancy has happened for religious motivations, in the protestant movement, it is herein noticed that the religious meanings expressed in the speeches point much more towards the fragility of this virtue than to the strengthening of political dimension in nursing ${ }^{(18)}$.

Discourse centered in the stereotype of angel-nurse is associated to the concept about the banality of evil, represented in the abyss between the gravity of acts and the shallowness of motivations of Nazis' acts, supported in a process of normalization of evil, as it is found in the speech of Rosa dos Ventos $2^{(21)}$.

In that sense, authors reinforce that in Nursing, countless examples of stereotypes of what is expected of a nurse are found, i.e., that she is kind, dedicated, caring, selfless, obedient and servile, what takes us back to the characteristics of the history of the profession and to its religious background. Those attributes are/were nothing more than those wished by the fathers, husbands, bosses or any other person who interacts/interacted with a woman ${ }^{(22)}$.

In that direction, the veil, the cross and the wings are elements of the composition of nurses' image that take back on the figure of an angel. That signification can be interpreted in articulation with the image of a nurse as a possible symbol of values, which leads her to the common sense of a selfless praxis, of submission, of donation and of serving ${ }^{(23)}$.

The fact that nurses are identified/identify themselves socially as angels has an ingrained intention to historically ensure the submission and subalternity of the profession, the disciplining of bodies, as well as the maintenance of the exploitation process of their work and the guaranteed profitability of health services ${ }^{(24)}$.
Furthermore, other two meanings of militancy are expressed in two subcategories: on one side, the heroic meaning, and on the other hand, implication as a social matter. The first one holds two faces, on one side it encourages militancy but otherwise it barely acknowledges its limitations. Therefore, militancy presents among its configurations the hero, marked by influences of the union militant and of the communist ${ }^{(25)}$.

The "heroic" meaning is exposed in literature as a ramification of the union militant and of the communist militant, in a form of base delegation for representation so the latter take action in defense of the profession. However, there are other denominations for the figure of the political militant, a configuration dated from 1975, the paid militant. And the French-origin configuration, dated from 1995, distanced militant.

Finally, the last meaning found was of the being implicated with social matters, as seen in Rosa dos Ventos 5, 6 and 11, herein identified as a convergent point of the entire study and which echoes in the assertion that militancy is built, produced and reproduced in people's lives, in social and collective spaces.

\section{Study limitations}

Limitations found in this study were related to the length of interviews, since many of them were longer than four hours, with analytical material about nursing, the nursing profession and the personal life of Brazilian nursing militants, what demand software data analysis of data in qualitative research.

\section{Contribution to nursing, health or public policies}

Fragility in valuing of the nursing profession is due to several reasons, such as negative stereotypes that still are present in nurses' praxis and low visibility of political sense in practice and knowledge, what results, oftentimes, in misinformation and generalization of nurses' work process. It is important to understand that the construction of nurses' militancy is linked to their individuality, but also to the work context, to their experiences and interactions with other professionals.

On the other hand, it is important to highlight that knowledge production in the political field of the profession may result in more political reflection upon nursing and health care, as well as in its quality and in nurses' satisfaction and life quality at work. As a consequence, this study brings important contributions for this profession, since it comprehends militancy through its vision by nurses who work and who live the stereotypes and their impacts in labor activities.

\section{CONCLUSIONS}

The convergence of findings with the established theoretical plan becomes fact - the improper meaning when related to sex studies as a social construction, the religious meaning when the genesis of nursing is identified, and the communist sense when the political moment of the country at the time is taken into consideration.

Otherwise, regarding the divergent findings in this study, taking the state of the art about the theme as base, which were 
the heroic meaning and the meaning implied as a social matter, we can highlight that their coexistence is found in the field of professional militancy and is restricted to the nurses who comprehend the meaning of defense and representation of the profession in a collective axis.

Therefore, it is evident that the political formation of militancy is dislocated from nursing training, it is produced and comprehended externally to the traditional training spaces and it is oftentimes made inviable through disciplinary and subjectification resources that are supported in systems and signs of professional militancy.

In conclusion, militancy signs are convergent with what is found in national and international literature. However, the different findings in hermeneutic and dialectic analysis were the heroic meaning and the meaning implied as a social matter, so the militant is almost never associated to positive aspects and, thus, this profile is infrequently encouraged in subjects.

In conclusion, the signs of militancy are convergent with what is put in national and international literature. However, the difference found in the hermeneutic and dialectical analysis was the heroic meaning and the social one. The militant is almost never associated with positive aspects and so is not encouraged in the subject this profile.

Individuals who build themselves politically are empowered as social beings, turning knowledge into power, causing a break in traditional models. Thus, how little encouragement for the construction of militants there is.

\section{REFERENCES}

1. Baltazar B. Encontros e desencontros da militância na vida cotidiana. Psicol Teor Pesqui. 2004;20:183-90. doi: 10.1590/ S0102-37722004000200011

2. Oliveira GN, Pena RC, Amorim SC, Carvalho SR, Azevedo BMS, Martins ALB. Novos possíveis para a militância no campo da Saúde Interface: a afirmação de desvios nos encontros entre trabalhadores, gestores e usuários do SUS. Interface: Comun Saúde Educ. 2009;13(Supl.1):523-9. doi: 10.1590 / S1414-32832009000500005

3. Geovanini T, Moreira A, Dornelles S, Machado WCA. História da Enfermagem: versões e interpretações. 3rd ed. Rio de Janeiro: Revintes; 2010

4. Collière MF. Promover a Vida das práticas das mulheres de virtude aos cuidados de Enfermagem. Coimbra (PT): Lindel; 1999.

5. Boulnois O. Être et représentation. Paris: Presses Universitaires de France; 1999.

6. Foucault M. As palavras e as coisas: uma arqueologia das ciências humanas. Lisboa: Portugal; 1969.

7. Foucault M. A Arqueologia do saber. Rio de Janeiro: Forense; 1986.

8. Foucault M. As Palavras e as Coisas: uma Arqueologia das Ciências Humanas. São Paulo: Martins Fontes; 2000.

9. Padilha ICS, Boresnstein MS. O método de pesquisa histórica na Enfermagem. Texto Contexto Enferm [Internet]. 2005 [cited 2018 Mar 10];14(4):575-84. Available from: http://www.scielo.br/pdf/tce/v14n4/a15v14n4.pdf

10. Meihy JCSB, Holanda F. História oral: como fazer, como pensar. São Paulo (SP): Contexto; 2007.

11. Instituto Brasileiro de Geografia e Estatística-(IBGE). Censo Demográfico 2009 [Internet]. Rio de Janeiro (RJ): 2014 [cited 2018 Mar 10]. Available from: https://sidra.ibge.gov.br/home/ipca15/brasil

12. Conselho Regional de Enfermagem - Seção Bahia (BR). Consulta ao conselho com relação ao quantitativo de profissionais: 2014 [Internet]. Salvador (BA): 2014 [cited 2018 mar 10]. Available from :http://ba.corens.portalcofen.gov.br/conselhoregional

13. Silva TOS, Nascimento MAA, Alencar BRA. Hermenêutica Dialética: uma experiência enquanto método de análise na pesquisa sobre acesso do usuário à assistência farmacêutica. Rev. Bras Promoção Saúde [Internet]. 2012 [cited 2018 Mar 10];25(2):243-50. Available from: http:// periodicos.unifor.br/RBPS/article/view/2236

14. Boulnois O. Être et représentation. Paris: Presses Universitaires de France; 1999.

15. Bourdieu P. A produção da crença: contribuição para uma economia dos bens simbólicos. Porto Alegre: Zouk; 2008.

16. Franco T. Alienação do trabalho: despertencimento social e desenraizamento em relação à natureza. Caderno CRH. 2011;24:171-91. doi: $10.1590 /$ S0103-49792011000400012

17. Foucault M. Vigiar e punir: nascimento da prisão. Petrópolis, RJ: Vozes; 1987.

18. Pedroso RC. Sob o olhar do poder: notas sobre o DEOPS e o aprisionamento de presos políticos no Brasil. Seminários, Crime, Criminalidade e Repressão no Brasil República [Internet] 2013 ]cited 2018 Mar 10];2. Available from: http://www.usp.br/proin/revistaseminarios3.pdf

19. Lima D, Porto F. Véu, cruz e asa: elementos de composição da imagem da Enfermeira [Internet]. 2014 [cited 2016 Mar 10]. Rio de Janeiro. Available from: http://www.lacenf.com.br/wp

20. Souza NRA esquerda militante: entre o engajamento pastoral e os revides locais. Rev Sociol Polit. 1999;12:131-46. doi: 10.1590/ S0104-44781999000100008

21. Arendt H. A condição Humana. Rio de Janeiro: Forense Universitária; 2013.

22. Pudal B. Los enfoques teóricos y metodológicos de la militância. Rev Sociol [Internet]. 2011 [ cited 2019 Jan 9];(25):17-35. Available from: https://core.ac.uk/download/pdf/132236106.pdf 
23. Foucault M. Ditos e Escritos, Vol. II: arqueologia das ciências e história dos sistemas de pensamento. Rio de Janeiro: Forense Universitária; 2000.

24. Almeida DB. Constituição de enfermeiras militantes: um estudo histórico e foucaultiano [Tese] [Internet]. Salvador: Universidade Federal da Bahia; 2017 [cited 2020 May 14]. 246 s. Available from: https://repositorio.ufba.br/ri/handle/ri/30638

25. Minayo MCS. O Desafio do Conhecimento: pesquisa qualitativa em Saúde. São Paulo: Hucitec; 2006. 